Jurnal Ilmu dan Teknologi Kesehatan

Vol 8, No 1, September 2020,

ISSN: 2338-9095 (Print)

ISSN: 2338-9109 (online)

\title{
The Influence of Testimony Video in Early Detection of Cervical Cancer
}

\author{
Siti Masitoh, Mardeyanti \\ Poltekkes Kemenkes Jakarta III, Indonesia \\ Email: imasmarkus@yahoo.co.id
}

\author{
Article history \\ Posted, Aug 5th, 2020 \\ Reviewed, Sept 10th, 2020 \\ Received, Sept 27th, 2020
}

\begin{abstract}
The high incidence of cervical cancer in Indonesia is up to almost $80 \%$. The cause of action is needed early detection through examination visual inspection with acetic acid/pap smear as a precaution to handling this disease. Women have avoided early detection through pap smear due to a lack of knowledge. The study's purpose was to determine the effect of health education with the module and video testimonials on increasing knowledge, attitude, and behavior in the early detection of cervical cancer by pap smear in Community Health Centers District Cipayung. This study uses a Quasi Experiment with pretest-posttest design in two groups, consisting of groups with a module method and groups by watching testimonial videos. Data obtained from questionnaires for knowledge, attitude, and behavior. The total samples are 70. Each group is 35 respondents. The results showed in the module group, and there were differences in knowledge before and after health education (p-value 0,000) and behavior (0.029). There are differences in knowledge ( $p$-value 0.046) and behavior (0,000). This study also shows differences in behavior after getting health education between modules and video testimonials (p-value 0.003). Education of respondents influences knowledge ( $p$-value 0,000). Health education using video testimonials increases attitudes and behaviors towards the early detection of cervical cancer.
\end{abstract}

Keywords: cervical cancer; early detection; video testimonials

\begin{abstract}
ABSTRAK
Tingginya angka kejadian kanker serviks di Indonesia hingga mencapai hampir 80\%, menjadi sebab diperlukan tindakan deteksi dini melalui pemeriksaan IVA/papsmear sebagai langkah antisipasi penanganan penyakit ini pada wanita usia subur. Deteksi dini melalui pemeriksaan IVA/papsmear selama ini dihindari oleh wanita usia subur karena pengetahuan yang kurang. Tujuan penelitian untuk mengetahui pengaruh pendidikan kesehatan dengan modul dan video testimoni terhadap peningkatan pengetahuan, sikap dan perilaku kader/ WUS dalam deteksi dini kanker serviks dengan pemeriksaan IVA/papsmear di wilayah kerja Puskesmas Kec. Cipayung tahun 2017. Penelitian ini menggunakan metode Quasi Experiment dengan Pretestposttest Design pada dua kelompok, yaitu kelompok dengan pendidikan kesehatan metode modul dan kelompok dengan melihat video testimoni. Data didapat dari kuesioner untuk pengetahuan, sikap dan perilaku. Jumlah sampel 70, masing-masing kelompok modul dan
\end{abstract}


video testimoni berjumlah 35 responden. Hasil penelitian menunjukkan pada kelompok modul terdapat perbedaan pengetahuan sebelum dan sesudah pendidikan kesehatan dengan p-value 0,000 dan perilaku 0,029. Pada kelompok video testimoni terdapat perbedaan pengetahuan dengan p-value 0,046 dan perilaku 0,000. Penelitian ini juga menunjukkan perbedaan perilaku setelah mendapatkan pendidikan kesehatan antara modul dan video testimoni dengan $\mathrm{p}$-value 0,003 . Pendidikan responden berpengaruh terhadap pengetahuan dengan p-value 0,000 .

Kata kunci: kanker servik, deteksi dini, video testimoni

\section{INTRODUCTION}

Worldwide, mortality caused by cervical cancer ranks second after cardiovascular disease. In developing countries ranks first as a cause of mortality in women of reproductive age, reaching nearly $80 \%$ of cases (WHO, 2008). Based on Estimates Globocan, International Agency for Research on Cancer (IARC), breast cancer incidents by 40 per 100,000 women, cervical cancer 17 per 100,000 women (Safrina, 2016).

Cervical and breast cancer are cancer, with the highest prevalence in Indonesia in 2013. Cervical cancer was $0.8 \%$, and breast cancer was 0.5\% (Riskesdas, 2015). Cervical cancer accounts for three-quarters of gynecologic cancers. Reports from several hospitals in Indonesia found that cervical cancer incidence was $65 \%-77,7 \%$ of the ten gynecological cancers. Cervical cancer ranks second for cancer in women in Indonesia after breast cancer. The low community alert level against cervical cancer and inadequate information about preventing early detection of cervical cancer is one reason the respondent does not want the visual inspection with the acetic acid (Gustiana, 2014). Westbrook and Fourie (2015) said that cervical cancer is more common in women from the lower middle class. One of the factors is the lack of opportunities, and limited access to information makes them less aware of cervical cancer. The high incidence of cervical cancer in Indonesia is caused by a lack of awareness of married women to do early detection (Pap smear test or visual inspection with the acetic acid) due to lack of knowledge them regarding the importance of visual inspection with the acetic acid (Dewi,2013).

Women's healthy behavior in maintaining reproductive health, especially preventing cervical cancer with early detection, is fundamental to prevent contracting the disease. Factors inhibiting women's motivation to carry out a visual inspection with acetic acid/ pap smears can be prevented through health promotion with appropriate methods. Women often have certain social groups to share their experiences, motivation that comes from a friend or someone who is experienced will 
be more in the hearts and minds. Testimonials are written or oral statements from personal figures or citizens stating the use of a product based on experience. Testimonials involve deeper emotions directly than logic, so the use of testimonials in health education for early detection of cervical cancer will be more meaningful than other methods in women of childbearing age. Socialization and campaigns about the dangers of cervical cancer are less adequate, particularly in the middle to lower class society (Atmi, 2017). Testimony about cervical cancer will present people with cervical cancer who are currently in treatment in the environment. The presence of people with cancer is expected to complete the information conveyed. It can directly interact with listeners, share real learning experiences, and discuss problems more deeply, not only logic but also emotions.

The incidence of cervical cancer in the world $85 \%$ percent occurs in developing countries. The cause is due to the absence of an effective screening program for women with low socioeconomic. The screening program is currently implemented to detect abnormal cell development signs at an early stage to enable early and rapid treatment. The program implemented in Indonesia is the visual inspection with acetic acid, a method of early detection of cervical cancer to identify pre-cancer (Solekhah, 2012). Women need to be given health education to improve their knowledge and attitudes about early detection of cervical cancer. Women to maintain reproductive health with early prevention will affect all aspects of women's lives of childbearing age and his family. The woman who has to know the causes, symptoms, and ways of preventing cervical cancer as well-meaning and benefits of early cancer detection cervix for himself will perform early detection of cancer cervix and motivate people to do early detection of cervical cancer (Mardianti, 2019).

Researchers are interested to know the effect of testimony video in health education on knowledge, attitude, and behavior women of fertile age in early detection of cervical cancer. They are expected to be motivated to do the visual inspection with acetic acid. This study is different from previous research on the Effectiveness of Audiovisuals and Booklets as Educational Media to Improve visual with acetic acid Screening Behavior (Silalahi, 2018). In this study, researchers used two groups, namely the module group and the video testimonial group. A video 
testimonial is a video of a woman who does the inspection visual with acetic acid. In both groups, pretest and post-test were conducted before and after reading the module and watching video testimonials.

\section{METHOD}

The research method uses a Quasiexperiment with Two Group Pretest Posttest. The study conducted pre and posttests on the module group and the video testimonial group simultaneously. Module groups are given health education by reading modules on cervical cancer and its prevention efforts. The Testimony video group is a group that gets health education about cervical cancer through video testimonials. It contains explanations of cervical cancer, prevention efforts, and a story directly from a woman who carried out early detection of cervical cancer using visual inspection with the acetic acid method. Bivariate analysis was performed with the Wilcoxon Signed Rank Test and the Mann-Whitney Test. The error level is set at $5 \%$ or $95 \%$ confidence level (Notoatmodjo, 2012). Multivariate analysis using the MANCOVA test.

\section{RESULTS AND DISCUSSION}

Table 1. Distribution of Respondent Characteristics

\begin{tabular}{lcccc}
\hline \multirow{2}{*}{ Characteristics } & \multicolumn{2}{c}{ Module } & \multicolumn{2}{c}{ Video testimonial } \\
\cline { 2 - 5 } & $\mathbf{N}(\mathbf{3 5})$ & \% $(35)$ & $\%$ \\
\hline Education & & & & \\
$\quad$ Low & 14 & 40 & 22 & 62.9 \\
$\quad$ High & 21 & 60 & 13 & 37.1 \\
\hline Work & 0 & 0 & 1 & 2.9 \\
$\quad$ Work & 35 & 100 & 34 & 97.1 \\
$\quad$ Not work & 5 & 14.3 & 10 & 28.6 \\
\hline Parity & 30 & 85.7 & 25 & 71.4 \\
$\quad$ Primi para & & & & \\
$\quad$ Multipara & 8 & 22.9 & 17 & 48.6 \\
\hline Married Age & 27 & 77.1 & 18 & 51.4 \\
$\quad$ 20 years & & & & \\
$\quad$ 20 years & & & & \\
\hline
\end{tabular}

The average age of respondents in the module group 41.03 and the video testimony group 38.83. Based on
Solekhah's research (2012), 59.2\% of women aged > 35 years have already examined Visual Inspection with Acid. 
Mirayashi Research (2014) aged 36-49 years, $31.8 \%$ had already examined visual inspection with acetic acid. Pertiwi (2015) $83.7 \%$ of respondents aged $>35$ years have had a visual inspection with acetic acid / Pap smear. Increasing age maturity level and strength of someone more mature in thinking and working. The group aged older adults consider themselves more vulnerable to disease than young adults, so that more precautions.

The study results, $40 \%$ of respondents had low education in the module group, and $62 \%$ in the video testimonial group. Education is essential in influencing one's behavior in decision making. According to Notoatmodjo (2014) education is a process; therefore, it automatically has input and output. The outputs of the education process are people who have broad insights and ways of thinking. Almost all respondents are unemployed. Work is an activity that must be carried out primarily to support his life and family. Not working is not a reason for a mother lacking knowledge, attitudes, and behaviors in the early detection of cervical cancer. However, women of childbearing age should have time to increase their knowledge. Research by Mirayashi (2014), as many as 33 people $(37.5 \%)$ of respondents who have done Visual Inspection with Acid work as housewives. The study results, $85.7 \%$ of women multipara in the module group and $71.4 \%$ in the video testimony group. Parity is essential in influencing one's knowledge, attitudes, and behavior in decision making, especially regarding early detection of cervical cancer by examining Visual Inspection with Acid or Pap smear. Research by Pertiwi (2015) of 49 that Pap smear / Visual Inspection with acetic acid, $87.8 \%$ were multiparous respondents.

The results showed that the respondent's married age in the module group was 27 people $(77.1 \%)$ with age 20 years and eight people $(22,9 \%)$ with age $<20$ years. Video testimonial group 18 people $(51.4 \%)$ with a marriage age category $>20$ years and 17 people $(48.6 \%)$ married age $<20$ years. According to the Pertiwi research (2015), 49 people did a Pap smear / Visual Inspection with acetic acid, only $12.2 \%$ with married age $<20$ years and $4.1 \%$ with married age $>35$ years. The results also showed $38.7 \%$ of respondents who were not Pap smear / Visual Inspection with acetic acid at the age of marriage $<20$ years. 
Table 2. Differences in Knowledge, Attitude, and Behavior in the Early Detection of Cervical Cancer Before and After Health Education with Module

\begin{tabular}{|c|c|c|c|c|c|c|}
\hline \multicolumn{2}{|c|}{ Dependent Variable } & \multirow{3}{*}{$\begin{array}{c}\text { Mean } \\
16.29 \\
19.40 \\
\end{array}$} & \multirow{3}{*}{$\begin{array}{c}\text { Median } \\
16.00 \\
20.00 \\
\end{array}$} & \multirow{3}{*}{$\begin{array}{c}\text { SD } \\
1.690 \\
2.341 \\
\end{array}$} & \multirow{3}{*}{$\begin{array}{c}\begin{array}{c}\text { Mean } \\
\text { Difference }\end{array} \\
3.11\end{array}$} & \multirow{3}{*}{$\begin{array}{r}\mathbf{p} \text {-value } \\
0,000\end{array}$} \\
\hline \multirow{2}{*}{ Knowledge } & Before & & & & & \\
\hline & After & & & & & \\
\hline \multirow{2}{*}{ Attitude } & Before & 42.97 & 40.00 & 6.918 & \multirow{2}{*}{0.66} & \multirow{2}{*}{0.914} \\
\hline & After & 43.63 & 43.00 & 6.107 & & \\
\hline \multirow{2}{*}{ Behavior } & Before & 4.03 & 4.00 & 2.695 & \multirow{2}{*}{0.88} & \multirow{2}{*}{0.029} \\
\hline & After & 4.91 & 5.00 & 2.188 & & \\
\hline
\end{tabular}

In knowledge, there is an average difference of 3.11 with a p-value of 0,000 . These results indicate a significant difference in knowledge about early detection of cervical cancer in the group module. The difference in the average attitude of respondents in module 0.66 with a p-value of 0.914. These results indicate no differences in respondents' attitudes before and after getting health education about early detection of cervical cancer with the module. Statistical test results on respondent behavior differences regarding early detection of cervical cancer before and after health education by the module method showed an average difference of 0.88 with a $p$-value of 0,029 . These results indicate that there are significant differences in respondent behavior in the early detection of cervical cancer.

Table 3. Differences in Knowledge, Attitude, and Behavior Before and After Health Education with Video Testimonial

\begin{tabular}{|c|c|c|c|c|c|c|}
\hline \multicolumn{2}{|c|}{ Dependent Variable } & Mean & Median & SD & $\begin{array}{c}\text { Mean } \\
\text { Difference }\end{array}$ & $\begin{array}{c}P \text { - } \\
\text { value }\end{array}$ \\
\hline \multirow{2}{*}{ Knowledge } & Before & 17.09 & 18.00 & 3.921 & \multirow{2}{*}{1.05} & \multirow{2}{*}{0.046} \\
\hline & After & 18.14 & 18.00 & 2.756 & & \\
\hline \multirow[t]{2}{*}{ Attitude } & Before & 39.00 & 39.00 & 6.651 & \multirow{2}{*}{2.37} & \multirow{2}{*}{0.039} \\
\hline & After & 41.37 & 42.00 & 5.369 & & \\
\hline \multirow[t]{2}{*}{ Behavior } & Before & 4.29 & 5.00 & 2.707 & \multirow{2}{*}{2.34} & \multirow{2}{*}{0,000} \\
\hline & After & 6.63 & 7.00 & 2.568 & & \\
\hline
\end{tabular}

The knowledge variable obtained an average difference of 1.05 , with a p-value of 0.046 . These results indicate significant differences in respondents' knowledge 
about early detection of cervical cancer with video testimonials. The difference in respondents' average attitude before and after health education with video testimonials was 2.37 , with a p-value of 0.039 . These results indicate differences in respondents' attitudes before and after getting health education about early detection of cervical cancer with video testimonials. Statistical test results on differences in respondent behavior regarding early detection of cervical cancer before and after health education using the video testimonial method show an average difference of 2.34 with a p-value of 0,000 . These results indicate that there are significant differences in respondent behavior in the early detection of cervical cancer.

Table 4. Differences in Knowledge, Attitude, and Behavior among Module with Video testimony in the Early Detection of Cervical Cancer

\begin{tabular}{|c|c|c|c|c|c|}
\hline \multicolumn{2}{|c|}{ Variable } & \multirow{2}{*}{$\begin{array}{c}\text { Mean Rank } \\
40.10\end{array}$} & \multirow{2}{*}{$\begin{array}{c}\text { Sum of Ranks } \\
1403.50\end{array}$} & \multirow{3}{*}{$\begin{array}{c}\mathbf{Z} \\
-11010\end{array}$} & \multirow{3}{*}{$\begin{array}{r}\text { p-value } \\
0.056\end{array}$} \\
\hline \multirow{2}{*}{ Knowledge } & Module & & & & \\
\hline & Video & 30.90 & 1081.50 & & \\
\hline \multirow{2}{*}{ Attitude } & Module & 39.01 & 1365.50 & \multirow{2}{*}{-1.447} & \multirow{2}{*}{0.447} \\
\hline & Video & 31.99 & 1119.50 & & \\
\hline \multirow{2}{*}{ Behavior } & Module & 28.43 & 995.00 & \multirow{2}{*}{$-2,956$} & \multirow{2}{*}{0.003} \\
\hline & Video & 42.57 & 1490.00 & & \\
\hline
\end{tabular}

The differences in knowledge, attitudes, and behaviors after respondents received health education between the module and video testimonials. For the knowledge variable, the p-value 0.056 results, this result is not statistically significant, so it can be concluded that there is no difference in knowledge between the module group and the video testimonial group. The respondents' attitude showed a p-value of
0.447. These results suggest no difference between the respondents' attitudes and group module video testimony about the early detection of cervical cancer. In the respondents' behavior obtained p-value 0.003 , this result shows that there are differences in the behavior of respondents between a module group with a video testimonial group after being given health education. 
Health education provided aims to provide information, add and change knowledge, attitudes, and behavior. In the module group, there was an increase in knowledge after being given health education. It was known the average value before health education was 16.29 to 19.40 after health education, with a p-value of 0,000 . It shows that there are significant differences in knowledge. In the video testimony group, it increased from 17.20 to 18.14 , with a $\mathrm{p}$ value of 0.048 . According to Notoatmodjo (2014) the tools used in health education activities aim to help deliver health messages to be more transparent. The target community can receive the message clearly and precisely. The teaching aids are arranged based on the principle that the five senses will capture the knowledge that exists in every human being. The more senses are stimulated, the target group will absorb more knowledge and understanding.

Each visual aid has a different intensity in helping and understanding one's problems. According to the researcher, an increase in respondents' good knowledge in the module group was due to the module being accompanied by more concrete explanations and pictures to understand more about the information conveyed. This study is the same as Mahanani (2016) research, which states there are differences in the effect of health education on the level of knowledge of women of childbearing age in conducting Visual Inspection with Acid examination with a p-value of 0.001 . Video is an educational aid or teaching aid that is included in hearing aids (audiovisual). According to Imran (2017), video is a modern instructional media by the times. According to the Imran research results, the increase occurred knowledge of young women after being given health education through video media. Video has better capabilities because it has audio and visual media types, so video media is one of the health promotion media that uses hearing aids, so it is expected that those who watch are motivated to do what is promoted. Knowledge about Pap smear and cervical cancer was necessary for predicting Pap test doing. Also, inadequate knowledge was introduced as the most crucial barrier to screening test from the perspective of women (Ashtarian, 2017)

This study's results obtained the attitude of respondents before and after health education in the module group, an increase of 42.97 to 43.63 . For video testimonials, there was an increase in the average attitude of respondents from 39.00 to 41.37 . For both health education models, there is an increase in the average attitude of respondents. Nevertheless, respondents' attitudes in the module group before and after health education were statistically 
different from the $\mathrm{p}$-value 0.914. In the video testimony group, there is a difference with $\mathrm{p}$-value 0.039 . This result shows the difference between the module group and the video testimonial group. However, after analyzing the attitude after being given health education and comparing the module group with the video testimonial group, the results were statistically not significant with a p-value 0.447. Notoatmodjo (2014) attitude is the readiness to react to objects in a particular environment as an appreciation of objects. According to investigators, the attitude is not an act or activity will but predisposes action behavior.

This study's results indicate that respondents' average behavior before and after health education with modules increased from 4.03 to 4.91 , with a p-value of 0.029 . which means there are differences in behavior before and after health education with modules. Likewise, the testimonial video group from 4.29 to 6.63 with a p-value of 0.000 means significant differences after watching the testimonial video. The final results of the analysis comparing the behavior between groups of modules with video testimonials found that the $\mathrm{p}$-value 0.003 . These results indicate significant differences between behavior in the module group and behavior in the video testimonial group after health education.

Health education makes an impact good for the community to increase their health confidence so that people are encouraged to do screening because they are more aware that they are at risk for cervical cancer. Once given, health education with audiovisuals and booklets of respondents is more likely to do IVA screening than those who received health education through audiovisual only (Silalahi, 2018).

Table 5. Test of between-subject effects

\begin{tabular}{lccccc}
\hline $\begin{array}{c}\text { Dependent } \\
\text { Variable }\end{array}$ & $\begin{array}{c}\text { Type III Sum } \\
\text { of Square }\end{array}$ & df & $\begin{array}{c}\text { Mean } \\
\text { Square }\end{array}$ & F & p-value \\
\hline Knowledge & 109,572 & 1 & 105,572 & 20,539 & 0,000 \\
\hline Attitude & 74,118 & 1 & 74,118 & $2,227$. & 0.140 \\
\hline Behavior & 0.596 & 1 & 0.596 & 0.093 & 0.762 \\
\hline
\end{tabular}

The analysis results determine the location of the influence of education on the dependent variable (knowledge, attitudes, and behavior). The results showed an influence of education on knowledge with a significant value of 0,000 . It indicates the 
influence of knowledge due to educational differences. Significant values for attitudes and behavior, 0.140 and 0.762 , indicate no influence on attitudes and behavior due to differences in respondents' education. According to Green's theory, a person's behavior about health is determined by the knowledge, attitudes, beliefs, traditions, and so on of the person or community concerned. The knowledge obtained by women about early detection of cervical cancer will be carried out in daily life (Notoatmodjo, 2014).

According to Susilo (2011), learning is a behavior change. Change is obtained from experiencing, observing, reading, imitating, solve problems, listen, follow directions. A person's education level affects the ability to receive information and knowledge and accept change. This study's results are not in line with research conducted by Rahmawati (2016), which concluded that the level of education does not entirely influence a person's level of knowledge about cervical cancer. However, the study states that knowledge is more influenced by the exposure of information obtained. This study did not show the influence of education on attitudes.

\section{CONCLUSION}

There is a difference in respondents' knowledge in the early detection of cervical cancer before and after health education in the module and video testimony groups. There were differences in respondent's behavior in the early detection of cervical cancer before and after health education in the video testimony group. Health education by video testimony effectively increases knowledge and behavior in the early detection of cervical cancer.

\section{ACKNOWLEDGMENT}

The researcher would like to express his deepest gratitude to the Health Polytechnic of the Ministry of Health, Jakarta III, who has helped sponsor this research.

\section{REFERENCE}

Atmi, R.T. 2017. Model of Health Information Sharing Behavior Among Patients in Cervical Cancer. Record and Library Journal, 4(2): 139-157

Ashtarian, H., Mirzabeigi, E.B.S, and Khezeli, M. 2017. Knowledge about Cervical Cancer and Pap Smear and the Factors Influencing the Pap test Screening among Women. Int $J$ Community Based Nurs Midwifery, 5(2): 188-195.

Dewi, L.N.M., Nunuk S, Pancrasia M. 2013. Hubungan Tingkat Pengetahuan Dan Sikap Wanita Usia Subur (WUS) Dengan Pemeriksaan Inspeksi Visual Asam Asetat (IVA) Di Puskesmas Buleleng 1. Jurnal Magister Kedokteran Keluarga, 1(1): pp. 57-66.

Gustiana, D. Dewi, Y.I dan Nurchayati, S. 2014. Faktor- Faktor Yang 
Berhubungan Dengan Perilaku Pencegahan Kanker Serviks Pada Wanita Usia Subur. Jom PSIK 1(2): $1-8$

Imran, F.A., Hasnah. 2017. Pengaruh Penyuluhan Kesehatan Melalui Media Video terhadap Peningkatan Pengetahuan Remaja Putri tentang Dampak Abortus Provokatus Kriminalis di Kelas X SMAN Gowa. Jurnal Kesehatan, 10(2): 61-67

Kementerian Kesehatan R.I. 2015. Riskesdas: Situasi Penyakit Kanker Pusat data dan Informasi Kementerian Kesehatan. Jakarta.

Kurniawidjaja, M., Erwandi, D., Pujiriani,I. 2013. Promosi Pengetahuan, Sikap, dan Keterampilan Berpola Hidup Sehat pada Kelompok Senam. Jurnal Kesehatan Masyarakat Nasional, 7 (9): 426-432. DOI: 10.21109/kesmas.v7i9.16

Larasati, E.D., Susanti, H.D., Prasetyo, Y.B. 2015. Efektivitas Penggunaan Media Promosi Kesehatan Video Yoga dalam Meningkatkan Motivasi Kesehatan Wanita Usia Subur tentang Kesehatan Reproduksi. Jurnal Keperawatan Universitas Muhammadiyah Malang, 6(2): 88101

Mahanani, P. R. 2016. Pengaruh pendidikan kesehatan terhadap tingkat pengetahuan dan sikap WUS dalam melakukan pemeriksaan IVA di Desa Pabelan. Skripsi. Surakarta: Universitas Muhammadiyah Surakarta

Maharsie, L and Indarwati. 2012. Hubungan Pengetahuan Ibu Tentang Kanker Serviks dengan Keikutsertaan Ibu Melakukan IVA
Test di Kelurahan Jebres Surakarta. Journal Gaster, 9(2): 46-54

Mirayashi, Deasy et al. 2014. Hubungan antara Tingkat Pengetahuan Tentang Kanker Servikas dan Keikutsertaan Melakukan Pemeriksaan Inspeksi Visual Asetat di Puskesmas Alianyang Pontianak. Jurnal Mahasiswa Kedokteran Untan. Accessed from http://jurnal.untan.ac.id on March 13, 2017

Mardianti,Citra. D. 2019. Faktor-Faktor Yang Berhubungan Dengan Perilaku Wanita Usia Dalam Melakukan Deteksi Dini Kanker Serviks Di Desa Jatimulya Wilayah Kerja Puskesmas Pedes Kabupaten Karawang. Jurnal Kebidanan, 8(1): 8-17. DOI : 10.26714/jk.8.1.2019.817

Notoatmodjo. 2012. Metodologi Penelitian Kesehatan. Jakarta: Rineka Cipta.

Notoatmodjo, 2014. Promosi Kesehan dan Ilmu Perilaku. Jakarta: Rineka Cipta

Nurhafni. 2017. Faktor-Faktor Yang Mempengaruhi Wanita Usia Subur Dalam Pemeriksaan Pap Smear di Puskesmas. Jurnal Riset Hesti Medan, 2(2): 142-152

Pertiwi, N. D. E. 2015. Faktor-Faktor Yang Berhubungan Dengan Kunjungan Pemeriksaan IVA/Pap Smear Pada Ibu-Ibu PKK Di Dusun Tajem Depok Sleman. Skripsi. Yogyakarta: STIKes Aisyiyah.

Safrina, L. Kartika, S. Marty M. 2016. Hubungan Pengetahuan, Sikap, dan Perilaku Wanita Dewasa Muda Terhadap Kanker Leher Rahim, Jurnal Mediapsi, 2(1):19-28 
Silalahi, V., Lismidiati, W., Hakimi, M. 2018. Efektivitas Audiovisual dan Booklet sebagai Media Edukasi untuk Meningkatkan Perilaku Skrining IVA. Jurnal Kesehatan Masyarakat. 14(3): 304-315. DOI : 10.30597/mkmi.v14i3.4494

Solekhah, Siti. 2011. Hubungan antara Karakteristik Wanita terhadap Kesadaran Inspeksi Visual dengan Asam Asetat (IVA) di Wilayah Kerja Puskesmas Jeluko Kudus, Jurnal Komunikasi Kesehatan, 2(01)

Sulastri, Thaha, R.M., Russeng, S.S. 2012. Pengaruh Penyuluhan Kesehatan Menggunkan Video dalam Pemeriksaan Payudara Sendiri terhadap Perubahan Pengetahuan dan Sikap Remaja Putri di SMAN 9 BalikPapan. Skripsi. Makasar: Universitas Hasanuddin

Susilo, R. 2011. Pendidikan Kesehatan dalam Keperawatan. Yogyakarta: Nuha Medika

Westbrook, L., \& Fourie, I. 2015. A feminist information engagement framework for gynecological cancer patients. Journal of Documentation, 71 (4): 752 - 774

WHO. 2008. World Health Statistics 2008.

Diunduh pada tanggal 22 Juli 2018 